\title{
Social and Economic Potential of Reclamation Development of Agroindustrial Complex of the Russian Federation
}

\author{
A.A. Ugryumova, M.P. Zamakhovsky, O.Yu. Grishaeva, and L.E. Pautova*
}

Federal State Budget Research Institution All-Russian Scientific Research Institute "Raduga", 140483 Kolomna, Russia

\begin{abstract}
The article presents the modern legal framework for the restoration and development of the land reclamation industry in the Russian Federation; specifics of the implementation of the State Program for the Development of Agriculture and the regulation of markets for agricultural products, raw materials and food, considering the implementation of the departmental program "Development of the Land Reclamation Complex of the Russian Federation". The formulation and content of the concept of the socio-economic potential of amelioration of the country have been concretized, which made it possible to identify the target orientation of such private potentials of the industry as: resource, innovation and technical, investment and entrepreneurial, economic, regulatory, social and personnel and information and digital. The classification of factors influencing the social and economic potential of land reclamation in the Russian Federation was substantiated and the relationship between the leading groups of these factors, focused on the financial and investment potential of agricultural producers, government support and the level of demand for agricultural products, was visualized. The official documents are detailed, which allow to manage the personnel potential of the industry, as the most important component of its reclamation potential. Sectoral guidelines for the development and formation of ameliorative potential at the federal level and the importance of regional programs for the development of rural areas are outlined. In the course of the study, it was revealed that there was no relationship in the regulatory documents on the formation and development of the potential of the reclamation industry of the agroindustrial complex, and it was concluded that it was necessary to improve the mechanisms of regulatory and methodological tools.
\end{abstract}

\section{Introduction}

Recently, the issue of economic security has been actualized as the main direction of state economic policy. The regulatory and strategic documents [1-7], and the corresponding national and federal projects determine the national social and economic activity to achieve

\footnotetext{
*Corresponding author: cosidanie35@yandex.ru
} 
economic and, in particular, food independence based on the formation of sustainable agriculture status. In order to implement the national strategic performance targets, it is required to use the aggregate potential of land reclamation development, which, according to the authors, combines such components as: resource potential, innovation and technical potential, investment and entrepreneurial potential, economic potential, regulatory potential, social and human potential, information and digital potential.

\section{Materials and methods}

In the course of study, theoretical and logical methods, the method of system analysis, processing and generalization of research results were used.

\section{Results and discussion}

The social and economic potential of land reclamation in the Russian Federation is a significant source of increasing the efficiency of reclamation farming and the food supply. The social and economic potential of the reclamation development of the Russian Federation [8] can be represented as (Fig. 1).

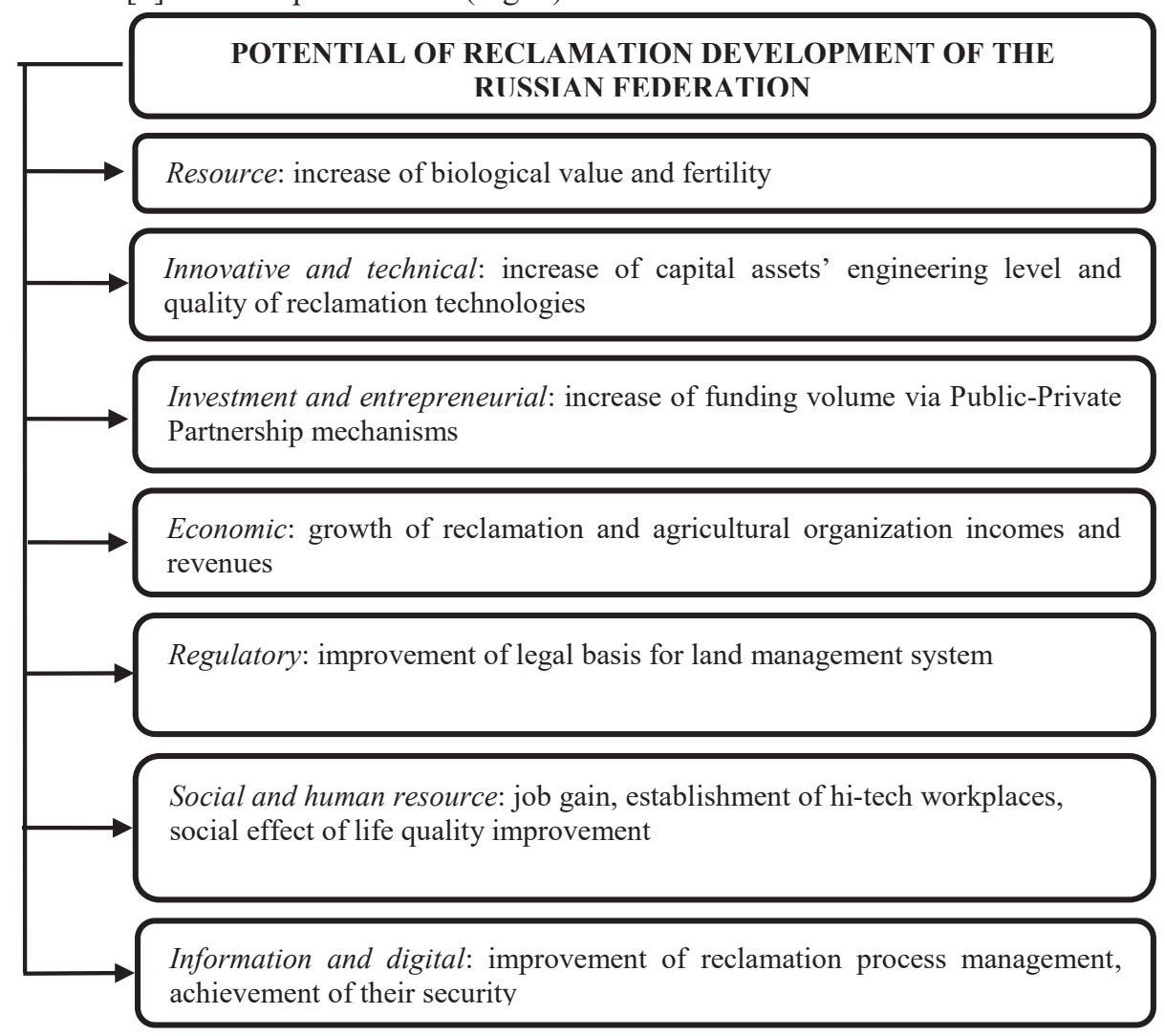

Fig. 1. Potential components of reclamation development of agroindustrial complex of the Russian Federation

The resource potential provides an increase in the fertility and biological value of lands as a result of various reclamation measures: irrigation, technical and cultural, phytoreclamation, agroforestry; and by preventing the disposal of land from agricultural 
circulation and restoration of the land fund as a result of the introduction of land into agricultural circulation

The innovative and technical potential of land reclamation development reflects the need to significantly increase the technical level of fixed assets of land reclamation distinguished by high wear rates throughout Russia, which affects the quality of land reclamation works and services. The realizing of innovative and technical potential of land reclamation ensures the growth of investment and entrepreneurial potential using the mechanisms of public-private partnership. The high degree of deterioration and obsolescence of equipment and structures of the reclamation water management complex impedes the implementation of innovative digital methods of production regulation. Consequently, each digital technology is seen as an addition to traditional control [9].

The agricultural activity on reclaimed lands with an increase in volumes, increasing the profitability of agricultural production on lands with increased fertility due to the reclamation made; an acceptable level of cost of reclamation work and the efficiency of reclamation activities are the main components of the economic potential of reclamation and sustainable development of rural areas of the country.

The regulatory and legal potential consists in resolving the issue of the legal status and ownership of ownerless lands, which will allow land reclamation organizations to work in a regulated manner and on time, to avoid loss of resources and time.

The social and human potential reflects possibilities of maintaining and increasing jobs, as well as creating high-tech jobs as the result of land reclamation expansion and the growth of agricultural production. It is based on the potential of the workforce as an integral characteristic of employees, which represents their maximum personal and professional opportunities to achieve professional and personal goals.

In order to manage the potential of amelioration of the Russian Federation, it is necessary to carefully identify and diagnose all significant factors affecting the land reclamation industry of the country.

All factors that have a significant impact on the land reclamation potential of the Russian Federation can be conditionally divided into three large groups. The visualization of these groups is shown in (Fig. 2).

The state program for the development of agriculture and the regulation of markets for agricultural products, raw materials and foodstuffs, launched in 2013 and designed for the period until 2020, has undergone changes regarding the issues of land reclamation and development: financing of land reclamation, which began in 2014 within the framework of the federal target of the program, ended ahead of schedule in 2018. From January 1, 2020, the status of the program to support land reclamation has changed, and the departmental program "Development of the land reclamation complex of the Russian Federation" was approved; which continues to implement the goals and objectives set for land reclamation organizations earlier, for the period 2014 - 2020 The timeframe for the implementation of the departmental program is defined as the period $2019-2025$, as well as the timeframe for the implementation of the state program continued until 2025. 


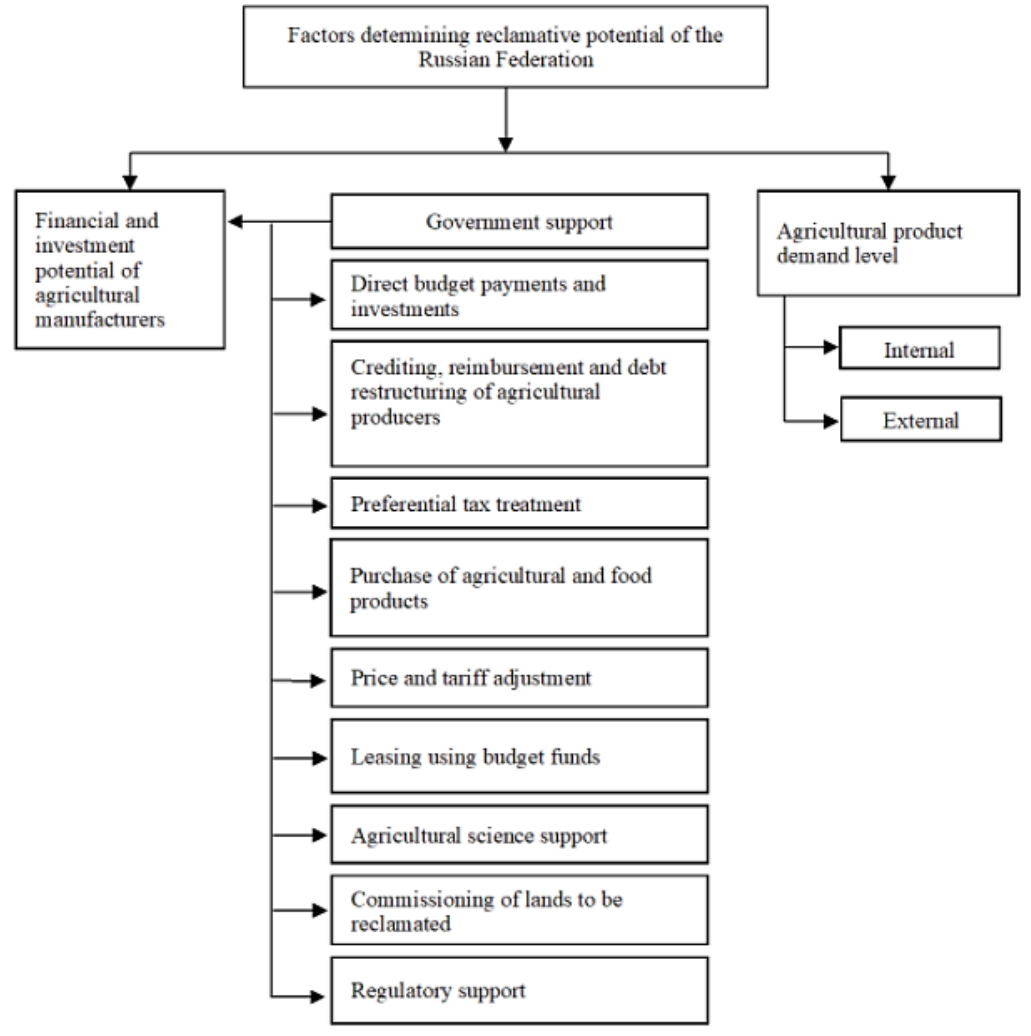

Fig. 2. Classification of factors affecting social and economic potential of the reclamation of the Russian Federation.

The regulatory documents for the period 2020-2022 especially indicate the financing of operation in such territories as the North Caucasian Federal District, Crimea, the Arctic zone, the Far Eastern Federal District, Sevastopol and the Kaliningrad Region. For the mentioned regions, measures are envisaged for putting land into operation through technical re-equipment, reconstruction and construction of new reclamation systems [5].

The relevance of the social and personnel potential study is determined by the fact that its structural parts are the determining factor in the formation of the potential of the reclamation industry of the agroindustrial complex of Russia. At the present stage of social and economic development, the solution of the issues of staffing of rural areas and the agroindustrial complex of Russia is engaged at all levels: federal, sectoral, regional, municipal.

In accordance with the Presidential Decree "On National Goals and Strategic Objectives for the Development of the Russian Federation for the period through to 2024" [1]; prerequisites for the formation of human resources can determine the implementation of priority tasks in the field of increasing labor productivity and supporting employment of the population until 2024.

Regarding the formation and development of human resources for land reclamation, at the federal and sectoral levels, the fundamental documents are:

- The Sustainable Development Strategy of Rural Areas of the Russian

- Federation for the period through to 2030 (The Order of the Government of the Russian Federation dated 02.02.2015 No. 151-r).

- The Federal Scientific and Technical Program for the Development of Agriculture through to 2017 - 2025 (The Decree of the Government of the Russian Federation dated August 25, 2017 No. 996). 
- The State Program of the Russian Federation "Integrated Development of Rural Areas"; the subprogram "The development of the labor market (human resources) in rural areas" (The Decree of the Government of the Russian Federation of May 31, 2019 No. 696 (in force as of 10/17/2020). The goal of this subprogram is to ensure the level of employment of the rural population by 2026 including the completed additional training (retraining), up to $70 \%$ of the working-age population; reducing the unemployment rate of the rural working-age population to 6.5\%; The implementation period - 2020 - 2025.

- The State Program for agricultural development and regulation markets for agricultural products, raw materials and food products through to 2025 (The Decree of the Government of the Russian Federation dated July 14, 2012 No. 717 (in force as of March 31, 2020) within the framework of the State Program, the effective Departmental Program "Development of the Land Reclamation Complex of Russia".

In order to implement these regulatory legal acts, the objective was set to fulfill the following benchmarks [2]: 1) achieving significant indicators in the production of competitive agricultural products at the domestic and external levels, 2) accelerating import substitution, ensuring food independence and security of Russia, 3) achieving a given pace exports, 4) the value of the added value created in agriculture in 2025 in the amount of 5774.3 billion rubles, 5) the index of the physical volume of investments in fixed assets of agriculture in 2025 in the amount of $121.8 \%$ in relation to the level 2017 year. However, without defining the features and directions of development of the personnel potential of all branches of the agro-industrial complex, the fulfillment of the specified indicators is questioned. This is justified by the fact that the personnel component in many branches of the agro-industrial complex is a "living" problem; that proves the relevance of human resources' formation and directions of its development.

At the regional level, regional programs for the development of rural areas are being developed. However, they do not always highlight separate subprograms, measures for the formation and development of human resources in the regional and sectoral specifics of the agro-industrial complex as a factor contributing to the achievement of sustainability in the development of rural areas and sectors of the agro-industrial complex.

Authors in early studies have identified the features of reclamation industry personnel structure and the trends of its formation [10-12]. In particular, the industry-specific features and differences between the personnel policy of the Department of Land Reclamation and the personnel policy of the Ministry of Agriculture of the Russian Federation were revealed. The results of these studies were the prerequisites for the study of scientific methodology, experience and technologies for the formation of human resources in land reclamation in modern conditions; identification of the leading industry trends in its development; development of recommendations to improve the efficiency of the use of personnel of the Department of Land Reclamation.

In order to identify current changes and trends in the development of the personnel potential of the industry, research has been carried out:

- The statistical analysis of personnel structure of Federal State Budgetary Institutions (FSBI) of the Department of Land Reclamation of the Russian Federation for federal districts;

- The revealed trends in the proportions of groups of workers in the structure of personnel Federal State Budgetary Institution of the Department of Land Reclamation;

- The statistical analysis of the age structure of the personnel of Federal State Budgetary Institutions (FSBI) of the Department of Land Reclamation of the Russian Federation by federal districts; 
- The revealed trends in the proportions of age groups of workers' personnel structure of the Federal State Budgetary Institution of the Department of Land Reclamation;

- The determined the specific weights of the number of age groups of FSBI workers of the Department of Land Reclamation in the number of age groups of workers in the agroindustrial complex of the Russian Federation;

- The revealed trends in the specific weights of the number of age employee groups of the Federal State Budgetary Institution of the Department of Land Reclamation in the number of age employee groups of the agroindustrial complex of the Russian Federation.

When developing directions for the human resource development it is advisable to consider documents on the long-term socio-economic development of the Russian Federation and the results of scientific and practical research in the land reclamation industry and the agro-industrial complex as a whole [13-15]. So, according to forecasts [6] for the period up through to 2036, in order to "ensure the acceleration of the potential growth rates of the Russian economy to the level of about 3\%"; the necessary condition for this is systemic changes in the development of human resources in the agroindustrial complex. Prerequisites at the state level are various measures for the scientific and technological development of the Russian Federation as one of the main priorities of state policy in the long term.

\section{Conclusions}

1. Thus, for the social and economic development of the Russian agroindustrial complex directive documents are being developed and implemented at various levels.

2. Based on the results of system analysis of the study scientific, methodological and practical features of the social and economic potential of land reclamation, indicators and factors for the social and economic development potential of land reclamation of the agro-industrial complex were determined.

3. In order to successfully implement the "State Program for the Development of Agriculture and Regulation of the Markets of Agricultural Products, Raw Materials and Food", it is necessary to improve the mechanisms of regulatory and methodological tools for the entire range of land reclamation measures.

4. Summarizing the results of regulatory framework analysis and directions of the social and economic potential of the land reclamation industry; it was revealed that there is no relationship in the regulatory documents on the formation and development of the potential of the Land Reclamation Department. This determines the need to update the regulatory, methodological, legislative and sectoral support for issues related to human resources in land reclamation and the agro-industrial complex, in general.

\section{References}

1. The Presidential Executive Order dated May 7, 2018 No. 204 "On National Goals and Strategic Objectives of the Russian Federation through to 2024"

2. State Program for Development of Agriculture and Regulation of Agricultural Commodity Markets through to 2025, The Decree of the Government of the Russian Federation dated 14.07.2012, 717 (2012) 
3. Federal Research and Development Program for Development of Agriculture for 2017 - 2025, The Decree of the Government of the Russian Federation dated August 25, 2017, 996 (2017)

4. State Program of the Russian Federation "Comprehensive Development of Rural Areas", subprogram "Development of Labor Market (Human Resources) in Rural Areas", The Decree of the Government of the Russian Federation dated 31.05.2019 696 (2019)

5. On Introducing Amendments to the State Program for Development of Agriculture and Regulation of Agricultural Commodity, Feedstock and Food Markets approved by the Decree of the Government of the Russian Federation No. 375 dated March 31 (2020)

6. Forecast for Sustainable Development of the Russian Federation through to 2036 approved by the Government of the Russian Federation on November 22 (2018)

7. Strategy for Sustainable Development of Rural Areas of the Russian Federation for the period through to 2030, The Decree of the Government of the Russian Federation dated 02.02.2015, 151-p (2015)

8. O.Yu. Grishaeva, World Science: Problems and Innovations: Collected papers of XLIII Int. Research and Practice Conf. in 2 volumes, 2, 32 (2020)

9. I.F. Yurchenko, Nizhnevolzhsky Agricultural University Complex Review: Science and Higher Professional Education, 1, 313 (2019)

10. Development of irrigation farming by regions of Russia: trends and prospects, Monograph, 189 (2019)

11. G.V. Olgarenko, A.A. Ugryumova, M.P. Zamakhovski, L.E. Pautova, Int. J. of Management, 11(7), 60 (2020) http://www.iaeme.com/

12. A.A. Ugryumova, M.P. Zamakhovski, L.E. Pautova, D.G. Olgarenko, Int. Scientific Conf. Geolinks, 1, 2, 253

13. M.B. Schepakin, E.F. Khandamova, V.A. Gubin, University Review. Food Technology, 2-3, 108 (2020)

14. A.F. Serkov, V.S. Chekalin, Economics of agricultural and processing enterprises, 12, 8 (2019)

15. S.A. Shelkovnikov, E.M. Lubkova, A.E. Shylova, Economics of agricultural and processing enterprises, 10, 27 (2019) 